\title{
The relationships between the digital game addiction, alexithymia and metacognitive problems in adolescents
}

\author{
Ergen yaş grubunda dijital oyun bağımlılığı, aleksitimi ve üst biliş \\ problemleri arasındaki ilişkinin incelenmesi \\ Mesut Yavuz², Narmin Nurullayeva², Selcan Arslandogdu², Ayca Cimendag², Merve Gunduz², Burcu \\ Goksan Yavuz ${ }^{3}$ \\ ${ }^{1}$ Assis. Prof., Istanbul Aydın Univesity, Department of Psychology; French Lape Hospital, Child and Adolescent Psychiatry, Istanbul Turkey \\ https://orcid.org/0000-0002-8957-6510 \\ 2Psk.,Istanbul Aydın Univesity, Department of Psychology, Istanbul, Turkey https://orcid.org/0000-0001-5085-6200, https://orcid.org/0000-0002-2195- \\ 4765, https://orcid.org/0000-0001-8557-6452, https://orcid.org/0000-0003-4261-4820 \\ 3 Assoc. Prof., Acıbadem Mehmet Ali Aydınlar University, Department of Psyhiatry,Istanbul Turkey https://orcid.org/0000-0002-1311-3798
}

\section{SUMMARY}

Objective: Digital game addiction has become a diffuse problem among adolescents. The aim of this study is to investigate the relationships between digital game addiction, alexithymia personality traits and metacognitive problems in adolescents. Method: 664 adolescents ( $51 \%$ male, $n=339,49 \%$ female, $n=325)$ from three secondary school in Istanbul were included in this study. The mean age of male and female participants was $12.89 \pm 1.29$, and $12.58 \pm 1.53$ respectively. Digital game addiction scale for children (DGASFC), 20 item Toronto alexithymia scale (TAS-20), and the metacognition questionnaire for children and adolescents (MCQ-C) were applied to participants. The correlation coefficients between the scales were analyzed with Spearmen's rank order correlation test. The predictability of TAS-20 and MCQ-C subscale scores, gender and age on the status of digital game addiction was tested with binary logistic regression analysis. Results: There were positive correlations between DGASFC and TAS-20 total $(r=.275)$, factor $1(r=.250)$, factor $2(r=.159)$, factor $3(r=.175)$ scores, and MCQ-C total $(r=.180)$ and factor $1(r=.109)$ scores. Results of the binary regression analysis revealed that TAS-20 factor 1 and factor 3, and MCQ-C factor 1 scores, and the gender predict the status of digital game addiction, significantly. Discussion: It is suggested that addressing the problems of identifying and expressing the emotions, and metacognitive problems may increase the treatment success of the adolescents presenting with digital game addiction.

Key Words: Adolescent, game addiction, alexithymia, metacognition

\section{ÖZET}

Amaç: Dijital oyun bağımlılığı, ergenler arasında yaygın bir problem haline gelmiştir. Bu araştırmanın amacı ergen yaş grubunda dijital oyun bağımlılı̆̆ı, aleksitimi kişilik özellikleri ve üst biliş sorunları arasındaki ilişkinin incelenmesidir. Yöntem: İstanbul'da üç orta okuldan 664 ergen (\%51 erkek, s=339, \% 49 kadın, s=325) çalışmaya dahil edilmiştir. Erkek ve kadın katılımcıların yaş ortalamaları sırasıyla $12.89 \pm 1.29$ ve $12.58 \pm 1.53^{\prime}$ dü. Katılımcılara çocuklar için dijital oyun bağımlılığı ölçeği (ÇiDOBÖ), 20 soruluk Toronto aleksitimi ölçeği (TAÖ-20) ve çocuklar için üst biliş ölçeği (ÜBÖ-ÇE) uygulanmıştır. Ölçekler arası korelasyonlar Spearman'ın sıralama korelasyon katsayısı testi ile analiz edilmiştir. TAÖ-20 ve ÜBÖÇE alt ölçek puanları, cinsiyet ve yaşın dijital oyun bağımlılığı olma durumu üzerine öngörücü etkisi ikili durum lojistik regresyon analizi ile değerlendirilmiştir. Bulgular: ÇiDOBÖ ve TAÖ-20 toplam ( $r=.275)$, faktör 1 $(r=.250)$, faktör $2(r=.159)$, faktör $3(r=.175)$ puanları ve de ÜBÖ-ÇE toplam ( $r=.180)$ ve faktör $1(r=.109)$ puanları arasında pozitif yönde korelasyonlar bulunmuştur. İkili durum regresyon analizi sonuçları TAÖ-20 faktör 1, faktör 3, ÜBÖ-ÇE faktör 1 puanları ve cinsiyetin dijital oyun bağımlılığı olma durumunu anlamlı ölçüde öngördüğünü göstermiştir. Sonuç: Duyguları tanımlama ve ifade etme sorunlarının ve üst biliş problemlerinin ele alınmasının dijital oyun bağımlıı̆̆ ile başvuran ergenlerde tedavi başarısını arttırabileceği kanaatine varılmıştır.

Anahtar Sözcükler: Ergen, oyun bağımlılığı, aleksitimi, üst biliş 


\section{INTRODUCTION}

Nowadays, digital games are widely played around the world, and adolescents are particularly prone to have digital game addiction (DGA) (1). In European countries, the rates of DGA of the adolescents were found to be between $0.6 \%$ and $1.6 \%$ (2). The rate of DGA of the children and adolescents was $11.9 \%$ for males and $2.9 \%$ for females, with an average of $8.5 \%$ in USA (3). There are several identified emotional and psychosocial risk factors in the development of DGA. It has been reported that emotional problems, loneliness, low self-esteem and low social functioning increase the risk of DGA (4). Additionally, over-engagement in digital games have negative consequences such as low academic success, increased rates of depression and anxiety disorders, deterioration of interpersonal relations, impulsiveness and delinquency $(3,6,7)$.

Alexithymia is a personality trait that is emphasized as a risk factor in the development of technology, internet and game addiction $(1,10)$, as well as development of many psychiatric disorders such as somatoform disorders (11), depression, anxiety disorders (12), impulse control disorders (13), obsessive and compulsive disorder (14). The main characteristics of alexithymia are problems in describing and expressing of emotions. Other basic features of alexithymia may be considered as externally oriented cognitive style, limited imagination and lack of empathic thinking $(15,16)$. Because of these type of limitations, individuals with alexithymia experience serious difficulties in establishing friendship relationships and usually have low social functioning (17). Gaetan et al. (1) suggested that, as alexithymia usually presents with flat emotional profile, and the virtual environment facilitates emotion regulation, for adolescents with alexithymia, online gaming may serve an attempt to control the alexithymic characteristics.

Another issue that may be emphasized in the development technology, internet, and online gaming addiction is the metacognitive abilities. Individuals with good metacognitive abilities can monitorize their own cognitive processes and identify and correct their own cognitive distortions and misinter- pretations (18). It has been reported that metacognitive problems play a role in the development of several psychiatric disorders such as substance addiction (19), internet and technology addiction (20), obsessive-compulsive disorder (21), and mood and anxiety disorders (18). It is also stated that there is a relationship between the metacognitive problems and the development of DGA (22). Spada and Caselli (22) suggested that positive metacognitions (e.g. online gaming reduces my negative feelings), and negative metacognitions (e.g. once I start online gaming I cannot stop) about online gaming are associated with the DGA.

Previous research reported that alexithymic personality traits (20), and metacognitive problems (22) play a role in the development of technology, internet and DGA. However, to the best of our knowledge, in adolescent population there is a limited number of study in the literature examining the relationship of these topics. Considering the increasing time spent of adolescents in online games, and psychological, social and physical negative consequences of DGA (23), this study aimed to investigate the relationships between alexithymia, metacognition problems and the DGA in adolescents.

\section{METHOD}

\section{Participants and Procedure}

The power analysis was performed. The results of the power analysis indicated that minimal required number of the both female and male participants were 47 . The study included 664 adolescents $(51 \%$ male, $\mathrm{n}=339$; $49 \%$ female, $\mathrm{n}=325$ ) from 3 secondary schools (two state schools, and one private school) in Küçükçekmece, İstanbul. The schools were determined according to the permission of Istanbul Provincial Directorate of National Education. The mean age of the girls was $12.58 \pm$ 1.53 and the mean age of the males was $12.89 \pm$ 1.29. The ethics committee permission was obtained from İstanbul Aydın University Clinical Ethics Committee. Initially, 682 adolescents were included in this study. According to the data obtained from the parents and department of psychological counseling and guidance services of the 
schools, the participants who were diagnosed with mental retardation, learning disorder, and pervasive developmental disorder, and who had visual and hearing disabilities and had poor reading and writing skills were excluded from the study due to the possibility of having problems in understanding and responding the scales correctly. So, eight adolescents were excluded due to neurodevelopmental problems and disabilities. The purpose of the study and the procedure were explained in detail to the participants and their families, and the written informed consent was obtained from both parents and adolescents. The participants completed the scales under the supervision of a researcher in their classrooms. Two adolescents wanted to leave the study during the procedure, and eight adolescents were excluded from the study because of insufficient data. Finally, the statistical analysis was performed on 664 adolescents.

\section{Instruments}

Digital game addiction scale for children (DGAS$F C$ ): The scale was developed by Hazar and Hazar (24) and contains four subscales (excessive focusing on playing and conflict, tolerance and excessive value about playing, delay in tasks and home works, deprivation) and 24 questions. DGASFC is a fivepoint Likert type scale, and minimum and maximum scores can be 24 and 120 . The scores between 73 and 96 indicates "addiction to digital games" and between 97 and 120 indicates "highly addicted to digital games". The validity and reliability study of the scale was performed on Turkish children and adolescents aged between 10 and 14 years and Cronbach's alpha value was found as 0.90 (24).

20 item Toronto alexithymia scale (TAS-20): TAS-20 is developed by Bagby et al. (8) and is a widely used scale for evaluating alexithymia all over the world. The scale contains 20 questions and is rated as fivepoint Likert type. It has three subscales: difficulty in identifying feelings (factor-1), difficulty in describing feelings (factor-2), and externally-oriented thinking (factor-3). TAS-20 was adapted to Turkish by Güleç et al. (9). Bolat et al. (25) reported that the scale could be used in the adolescent population. The scores obtained from the scale can be between 20 and 100, and the scores $\geq 59$ on the scale indicate alexithymia (9). The Cronbach's alpha value of TAS-20 was found as 0.78 in adolescent population (25).

The metacognition questionnaire for children and adolescents (MCQ-C): MCQ-C was developed by Bacow et al. (26) and evaluates metacognition problems of the children and adolescents. The Turkish validity and reliability study was conducted by Irak (27). The Cronbach alpha value of the MCQ-C on Turkish children and adolescent population was found as 0.73 . The four-point Likerttype scale includes four subscales (positive metaworry, negative meta-worry, superstitious, punishment and responsibility beliefs, cognitive monitoring) and 24 questions. The lowest and highest scores that can be obtained from the scale are 24 and 96, respectively. Higher scores indicate more severe metacognitive problems.

\section{Statistical Analysis}

Those who received a score of $\geq 73$ from the DGASFC scale considered as the addicted group, and those who scored $<73$ points considered as the non-addicted group. Kolmogorov-smirnov test revealed that the data was not normally distributed $(p<0.05)$. The mean scores, standard deviations of the scales were calculated. Correlation coefficients between the DGASFC, TAS-20 and MCQ-C scores were analyzed by Spearman's rank correlation test. Backward binary regression analysis was performed in order to explore whether subscale scores of TAS20, MCQ-C, age and sex were related to DGA. The level of statistical significance was accepted at $<0.05$ and $<0.001$ levels.

\section{RESULTS}

Total scores of DGASFC, TAS-20, MCQ-C of the females were $42.83 \pm 16.41, \quad 49.70 \pm 10.08$, $57.42 \pm 10.99$; and of the males were $52.29 \pm 18.21$, $50.53 \pm 10.55,56.35 \pm 10.37$, respectively. Scale and subscale mean scores and standard deviations of females and male participants are presented in Table 1.

There were positive correlations between DGAS- 
Yavuz M, Nurullayeva N, Arslandogdu S, Cimendag A, Gunduz M, Goksan Yavuz B.

Table 1: Mean scores and standard deviations of the DGASFC, TAS-20, and MCQ-C of the participants

\begin{tabular}{llll}
\hline \multirow{2}{*}{ DGASFC } & Gender & $\mathrm{M}$ & $\mathrm{SD}$ \\
\cline { 2 - 4 } & Female & 42.83 & 16.41 \\
\hline \multirow{2}{*}{ TAS-20 F1 } & Fale & 52.29 & 18.21 \\
\cline { 2 - 4 } & Male & 15.94 & 5.95 \\
\hline \multirow{2}{*}{ TAS-20 F2 } & Female & 12.79 & 6.38 \\
\cline { 2 - 4 } & Male & 12.60 & 4.01 \\
\hline \multirow{2}{*}{ TAS-20 F3 } & Female & 20.98 & 4.16 \\
\cline { 2 - 4 } & Male & 21.84 & 3.79 \\
\hline \multirow{2}{*}{ TAS-20 total } & Female & 49.70 & 10.08 \\
\cline { 2 - 4 } & Male & 50.53 & 10.55 \\
\hline MCQ-C F1 & Female & 10.53 & 3.67 \\
\cline { 2 - 4 } & Male & 11.12 & 4.17 \\
\hline MCQ-C F2 & Female & 15.10 & 4.45 \\
\cline { 2 - 4 } & Male & 15.64 & 4.58 \\
\hline MCQ-C F3 & Female & 14.89 & 4.36 \\
\cline { 2 - 4 } & Male & 14.29 & 4.57 \\
\hline MCQ-C F4 & Female & 16.99 & 4.01 \\
\cline { 2 - 4 } & Male & 16.51 & 4.39 \\
\hline MCQ-C total & Female & 57.42 & 10.99 \\
\cline { 2 - 4 } & Male & 56.35 & 10.37 \\
\hline
\end{tabular}

M: Mean, SD:Standart Deviation, DGASFC= Digital game addiction scale for children TAS- $20=20$ item Toronto alexithymia scale; MCQ-C =The metacognition questionnaire for children; F1:Factor1, F2:Factor2, F3:Factor3, F4:Factor 4 FC scores and TAS-20 total $(\mathrm{r}=.275)$, TAS-20 factor $1(\mathrm{r}=.250)$, factor $2(\mathrm{r}=.159)$, factor $3(\mathrm{r}=.175)$ scores, significantly $(\mathrm{p}<0.001)$. There were positive correlations between DGASFC scores and MCQ-C total $(\mathrm{r}=.109, \mathrm{p}<0.05)$, and MCQ-C factor 1 $(\mathrm{r}=.180, \mathrm{p}<0.001)$ scores, significantly. Correlation coefficients between the DGASFC scores, and TAS-20, MCQ-C total and subscale scores are presented in Table 2.

The prevalence of DGA in adolescents was $9.5 \%$ $(n=63)$. The addiction rates were found as $5.2 \%$ for females $(n=17)$, and $13.5 \%(n=46)$ for males.
Binary logistic regression analysis results indicated that, TAS-20 factor 1 (o.r $=1.080, \mathrm{p}<0.001)$ and factor 3 (o.r $=1.075, \mathrm{p}=0.044)$ scores, and gender (o.r $=0.404, \mathrm{p}=0.001)$ significantly predict the status of digital game addiction. There were no significant predictive effects of age, TAS-20 factor 2, MCQ-C factor 2, factor 3 and factor 4 total scores on the status of digital game addiction $(p>0.05)$. The results of the backward binary logistic regression analysis are presented in Table 3.

\section{DISCUSSION}

The results of this study indicate that difficulty in identifying emotions and excessive externally-oriented thinking in alexithymia, and positive metaworry problems increase the risk of DGA in early adolescence. We found that the prevalence of DGA were $5.2 \%$ for females, and $13.5 \%$ for males. Consistent with the literature $(6,28)$, the results revealed that being male predicts the development of DGA. In our study, age did not have a significant effect on the status of DGA. However, it should be considered that our sample includes only adolescents between 12-14 years of age, and we suggest that this may limit the effect of age on the status of DGA.

Difficulties in recognizing emotions may lead the individuals to problems in understanding his/her own negative affect, and the cognitive processes related to negative affect (29). The individuals, who do not have sufficient comprehension of negative affect and its revealing cognitive processes, may have more inclination to several mental disorders such as anxiety disorders, depression and beha-

Table 2: Correlation analysis of the DGASFC total scores, and MCQ and TAS-20 total and subscale scores.

\begin{tabular}{|c|c|c|c|c|c|c|c|c|c|}
\hline DGASFC & TASF1 & TASF2 & TASF3 & MCQF1 & MCQF2 & MCQF3 & MCQF4 & MCQ-t & TAS - \\
\hline \multirow[t]{10}{*}{-} & $.250 * *$ & $.159^{* *}$ & $.175^{* *}$ & $.180^{* *}$ & .073 & .082 & .014 & $.109^{*}$ & $.275^{* *}$ \\
\hline & - & $.586^{* *}$ & .034 & $.088^{*}$ & $.206^{* *}$ & $.152 * *$ & .038 & $.179 * *$ & $.852 * *$ \\
\hline & & - & .051 & .022 & $.187 * *$ & $.120^{*}$ & .029 & $.131 *$ & $.771 * *$ \\
\hline & & & - & .022 & .047 & .053 & $.178^{* *}$ & $.101^{*}$ & $.448 * *$ \\
\hline & & & & - & .005 & $.105^{*}$ & .074 & $.390 * *$ & .057 \\
\hline & & & & & - & $.544 * *$ & $.268^{* *}$ & $.720 * *$ & $.192 * *$ \\
\hline & & & & & & - & $.385^{* *}$ & $.796 * *$ & $.125^{*}$ \\
\hline & & & & & & & - & $.647 * *$ & .040 \\
\hline & & & & & & & & - & $129 *$ \\
\hline & & & & & & & & & - \\
\hline
\end{tabular}

Spearman's rank order correlation test, DGASFC = Digital game addiction scale for children; TAS-t=Toronto alexithymia scale total scores; MCQ-t= The metacognition questionnaire total scores; F1: Factor 1, F2: Factor 2, F3: Factor 3, F4: Factor $4, * \mathrm{p}<0.05, * * \mathrm{p}<0.001$, bold: statistically significant 
Table 3: Predictive effects of alexithymia, metacognition problems, gender and age on the status of digital game addicton $\begin{array}{lllllll}\text { Step } 6 & \text { B } & \text { Wald } & \text { S.E } & \text { O.R (Exp B) } & \text { p } & \% \text { \% C.I (Low-High) }\end{array}$

Addicted: $(9.5 \%, \mathrm{n}=63)$

Non addicted $(91.5 \%, \mathrm{n}=601)$

\begin{tabular}{lllllll}
\hline Constant & -6.348 & 38.882 & 1.018 & 0.002 & $<0.001$ & \\
\hline TAS-20 F1 & 0.077 & 12.485 & 0.022 & 1.080 & $<0.001$ & $1.035-1.128$ \\
\hline TAS-20 F3 & 0.072 & 4.055 & 0.036 & 1.075 & 0.044 & $1.002-1.153$ \\
\hline MCQ-C F1 & 0.131 & 16.586 & 0.032 & 1.339 & $<0.001$ & $1.071-1.213$ \\
\hline Gender (categorical) & -0.907 & 8.740 & 0.307 & 0.404 & 0.003 & $0.221-0.737$
\end{tabular}

Backward binary logistic regression analysis.

Model 6; Excluded variables: Age, TAS-20 F2; MCQ-C F2, F3, F4;

DGASFC $=$ Digital game addiction scale for children, TAS-20: 20 item Toronto alexithymia scale; MCQ-C $=$ The Metacognition questionnaire for children and adolescents. F1: Factor 1, F2: Factor 2, F3: Factor 3, F4: Factor 4.* O.R: odds ratio, C.I $=$ confidence interval, $\mathrm{p}<0.05$, $* * \mathrm{p}<0.001$.

vioral problems (17). Digital games may bring a sense of strength, success and pleasure that are difficult to reach in real life. So, digital games may serve as a facility to improve the negative affect that may be seen in depression and anxiety disorder frequently. These data may explain the increased risk of DGA in adolescents who experience problems in recognizing the emotions. Adolescents with anxiety disorders have also the increased risk of introversion and social isolation (30). We suggest that digital gaming may play a compensatory role in the situation of social dysfunction and concomitant negative affect, and the individual with high anxiety levels may proceed to DGA. Impulse control disorders have also been reported to increase the risk of game addiction (3). The inability to express feelings which is the one of essential features of alexithymia may increase the risk of DGA by increasing impulse control problems in adolescents (10) and this may explain our results. It was reported that significant rate of adolescents play war and adventure games (31). Impulse control problems may especially be important in developing DGA about those type of aggressive games. In order to improve our knowledge about this topic, further studies should be performed about the relationships between impulse control problems and aggressive games.

In our study, it was found that positive metacognitive problems increase the risk of DGA. Positive metacognitive problems include the cognitive processes and beliefs point out that worrying is a good condition, and will bring benefit in emotional, academic and social field (e.g. "If I worry about something, I'll have less problems in the future", "Being worried helps me solve my problems"). This situation may prevent the individual from developing a solution for the negative emotions such as anxiety and stress, and the individual can progress to DGA as the severity and duration of negative affect prolongs. In addition, positive metacognition problems may also lead to an exaggeration in affirming consequences of game addiction, as "spending more time on games makes me feel good", "if I play more, I will have more friends and I will be less bored". This information may explain the relation between DGA and positive metaworrying problems in adolescents revealed by our study results.

Our study should be considered with its limitations. The cross-sectional nature of our study does not provide any clear cause-and-effect relationship. In addition, our study was conducted on adolescents aged between 12 and 14 years due to the validity of the DGASFC in adolescents under 14 years of age. Research in different age groups should contribute to our knowledge in this issue. Nevertheless, to the best of our knowledge, our study is also the first one in the international literature which focuses on these issues altogether. Therefore, we believe that it will make a significant contribution to the literature.

\section{CONCLUSION}

The results of our study suggest that the therapeutic interventions for identification and expression of the negative feelings in the adolescents with DGA may provide positive results in treatment. So, we suggest that providing the adolescent a secure therapeutic environment to explore and express his/her stress, anxiety or depressive feelings will improve the results of the treatment in DGA. Additionally, dealing with metacognitive problems in the therapeutic process may increase treatment success. For example, after revealing the cognitive 
problems such as "if I play more, I will have more friends", the clinicians may ask the question "let's think about your thoughts, yes you may have some point. However, I wonder can you have more friends if you make plan about the time limit of playing the digital games."
Correspondence address: Assis. Prof. Mesut Yavuz, Istanbul Aydın Univesity, Department of Psychology; French Lape Hospital, Child and Adolescent Psychiatry, Istanbul, Turkey mesutyavuzdr@gmail.com

\section{REFERENCES}

1. Gaetan S, Brejard V, Bonnet A. Video games in adolescence and emotional functioning: Emotion regulation, emotion intensity, emotion expression, and alexithymia. Comput Human Behav 2016; 61:344-49.

2. Müller KW, Janikian M, Dreier M, Wölfling K, Beutel ME, Tzavara C, Richardson C, Tsitsika A. Regular gaming behavior and internet gaming disorder in European adolescents: results from a cross-national representative survey of prevalence, predictors, and psychopathological correlates. Eur Child Adolesc Psychiatry 2015; 24:565-74.

3. Gentile DA. Pathological video-game use among youth ages 8-18: A national study. Psychol Sci 2009; 20:594-602.

4. Lemmens JS, Valkenburg PM, Peter J. Psychosocial causes and consequences of pathological gaming. Comput Human Behav 2011; 27:144-52.

5. Gentile DA, Choo H, Liau A, Sim T, Li D, Fung D, Khoo A Pathological video game use among youths: A two-year longitudinal study. Pediatrics 2011; 127: e319-29.

6. Demirtaş Madran HA, Ferligül Çakılcı E. The relationship between aggression and online video game addiction: a study on massively multiplayer online video game players. Anadolu Psikiyatri Derg 2014;15:99-107.

7. Wan CS, Chiou WB. Why are adolescents addicted to online gaming? An interview study in Taiwan. Cyberpsychol Behav 2006; 9:762e6

8. Bagby RM, Parker JDA, Taylor GJ. The twenty item Toronto Alexithymia Scale--I: Item selection and cross-validation of the factor structure. J Psychosom Res 1994; 38:23-32.

9. Güleç H, Köse S, Yazıcı Güleç M, Çıtak S, Evren C, Borckardt J, Sayar K. Yirmi soruluk Toronto Aleksimi Ölçeği'nin Türkçe uyarlamasının geçerlik ve güvenirliğinin incelenmesi. Klin Psikofarmakol B 2009;19:213-19.

10. Bolat N, Yavuz M, Eliaçık K, Zorlu A. The relationships between problematic internet use, alexithymia levels and attachment characteristics in a sample of adolescents in a high school, Turkey. Psychol Health Med 2018; 23:604-11.

11. Burba B, Oswald R, Grigaliunien V, Neverauskiene S, Jankuviene $\mathrm{O}$, Chue P. A controlled study of alexithymia in adolescent patients with persistent somatoform pain disorder. Can J Psychiatry 2006; 51:468-71.

12. Hamaideh SH. Alexithymia among Jordanian university students: Its prevalence and correlates with depression, anxiety, stress, and demographics. Perspect Psychiatr Care 2018; 54:27480 .

13. Fossati A, Acquarini E, Feeney JA, Borroni S, Grazioli F, Giarolli LE, Franciosi G, Maffei C. Alexithymia and attachment insecurities in impulsive aggression. Attach Hum Dev $2009 ; 11: 165-82$.

14. Wu C, Wu R. Self-inconsistency, alexithymia and obsessionscompulsions. Chin Ment Health J 2006; 20:513-16.

15. Grynberg D, Luminet $\mathrm{O}$, Corneille $\mathrm{O}$, Grèzes $\mathrm{J}$, Berthoz $\mathrm{S}$ Alexithymia in the interpersonal domain: A general deficit of empathy? Pers Individ Dif 2010; 49:845-50.

16. Feldmanhall O, Dalgleish T, Mobbs D. Alexithymia decreases altruism in real social decisions. Cortex 2013; 49:899-904.

17. Honkalampi K, Tolmunen T, Hintikka J, Rissanen ML, Kylmä J, Laukkanen E. The prevalence of alexithymia and its relationship with youth self-report problem scales among Finnish adolescents. Compr Psychiatry 2009; 50:263-68.

18. Wells A. Emotional disorders and metacognition: Innovative cognitive therapy. 2000, Chichester, UK: Wiley.

19. Hajloo N, Sadeghi H, Nadinleoi KB, Habibi Z. The role of metacognition in students' addiction potential tendency. Int $\mathbf{J}$ High Risk Behav Addict 2014;3: e9355.

20. Uzal G, Yavuz M, Akdeniz B, Çallı S, Bolat N. Investigating the relationships between alexithymia characteristics, meta-cognitive features and mental problems in high school students in İstanbul. Anadolu Psikiyatri Derg 2018;19:478-84.

21. Wells A, Papageorgiou C. Relationships between worry, obsessive-compulsive symptoms and meta-cognitive beliefs. Behav Res Ther 1998; 36:899-913.

22. Spada MM, Caselli G. The Metacognitions about Online Gaming Scale: Development and psychometric properties. Addict Behav 2017; 64:281-86.

23. Jeong EJ, Kim DH. Social activities, self-efficacy, game attitudes, and game addiction. Cyberpsychol Behav Soc Netw 2011; 14:213-21.

24. Hazar Z, Hazar M. Çocuklar İçin Dijital Oyun Bağımlılığı Ölçeği. Journal of Human Sciences 2017;14:203-16.

25. Bolat N, Yavuz M, Eliaçık K, Zorlu A, Evren C, Köse S. Psychometric properties of the 20-Item Toronto Alexithymia Scale in a Turkish adolescent sample. Anadolu Psikiyatri Derg 2017;18:362-68.

26. Bacow TL, Pincus DB, Ehrenreich JT, Brody LR. The metacognitions questionnaire for children: Development and validation in a clinical sample of children and adolescents with anxiety disorders. J Anxiety Disord 2009; 23:727-36.

27. Irak M. Üstbiliş ölçeği çocuk ve ergen formunun Türkçe standardizasyonu, kaygı ve obsesif-kompülsif belirtilerle ilişkisi. Türk Psikiyatri Derg 2012;23:47-54.

28. Schmitt ZL, Livingston MG. Video game addiction and college performance among males: results from a 1 year longitudinal study. Cyberpsychol Behav Soc Netw 2015;18:25-9.

29. Larsen JK, Brand N, Bermond B, Hijman R. Cognitive and emotional characteristics of alexithymia: a review of neurobiological studies. J Psychosom Res 2003;54:533-41.

30. Rao PA, Beidel DC, Turner SM, Ammerman RT, Crosby LE, Sallee FR. Social anxiety disorder in childhood and adolescence: descriptive psychopathology. Behav Res Ther 2007;45:1181-91.

31. Durak ÖG, Ünal Ş, Erdoğan A, Bal F. Lise öğrencilerinde problemli internet kullanımı ile saldırgan davranışların ilişkisi: Özel Ahmet Şimşek Anadolu Lisesi örneği. TISEJ 2018;53:21728. 